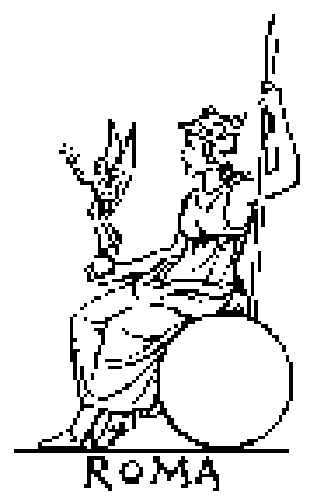

Two Roman Hoards of Coins from Egypt

Author(s): J. G. Milne

Source: The Journal of Roman Studies, Vol. 10 (1920), pp. 169-184

Published by: Society for the Promotion of Roman Studies

Stable URL: http://www.jstor.org/stable/295801

Accessed: 13/06/2014 05:05

Your use of the JSTOR archive indicates your acceptance of the Terms \& Conditions of Use, available at http://www.jstor.org/page/info/about/policies/terms.jsp

JSTOR is a not-for-profit service that helps scholars, researchers, and students discover, use, and build upon a wide range of content in a trusted digital archive. We use information technology and tools to increase productivity and facilitate new forms of scholarship. For more information about JSTOR, please contact support@jstor.org. 


\section{TWO ROMAN HOARDS OF COINS FROM EGYPT.}

By J. G. MILNE, M.A.

The two hoards of fourth-century Roman bronze coins here described were obtained in Egypt by Professor Petrie : and, as they cover a period on which not much work has been done, a detailed account of their contents may be of value.

The classification adopted is by means of reverse types and mints. It does not seem necessary to refer at length to the obverse types, which exhibit little variation in most reigns concerned : any points of interest are mentioned in the notes prefixed to each list. The types are arranged in what appears to be their chronological order: the earlier issues, mainly of Constantinus I and his sons, which are represented only by stray specimens, are grouped together.

HOARD A.

Note :-The obverse types of Julianus Caesar and Constantius Gallus used at different mints vary, not only in minor details of treatment of the bust, but in the division and titles of the legend. The legends of Julianus are :-

\begin{tabular}{|c|c|c|c|}
\hline Alexandria & & . & DNIVLIANVS NOBCAES. \\
\hline Antioch & & . & DNIVLIANV SNOBCAES. \\
\hline Constantinople and & Thessalonica & & DNCLIVLIANVSNOBCAES. \\
\hline Cyzicus & . & . & DNFLCLIVLI AN \\
\hline Nicomedia & . & . & DNIVLIANVS NOBCAESAR. \\
\hline Rome and Siscia & .. & .. & DNCLIVL IANVSNC. \\
\hline
\end{tabular}

Those of Constantius Gallus are :-

$\begin{array}{llllll}\text { Alexandria and Antiocb } & . . & . . & \ldots & \text { DNCONSTANTI VSNOBCAES. } \\ \text { Constantinople and Nicomedia } & . . & \ldots & \text { DNFLCLCONSTANTIVSNOBCAES. } \\ \text { Cyzicus .. } & . . & . . & . . & . . & \text { DNCONSTAN TIVSNOBCS. }\end{array}$

The bust of Julianus at Rome and Siscia has a cuirass only: elsewhere, a paludamentum and cuirass.

In the reverse type FELTEMPREPARATIO, the legend is at most mints divided - TEMP REPA-, but at Constantinople and Nicomedia the divisions - TEMPRE PA- and -TEMPR EPA- are equally common: the latter also occurs rarely at Cyzicus.

\section{MISCELI.ANEOUS EARLIER ISSUES.}

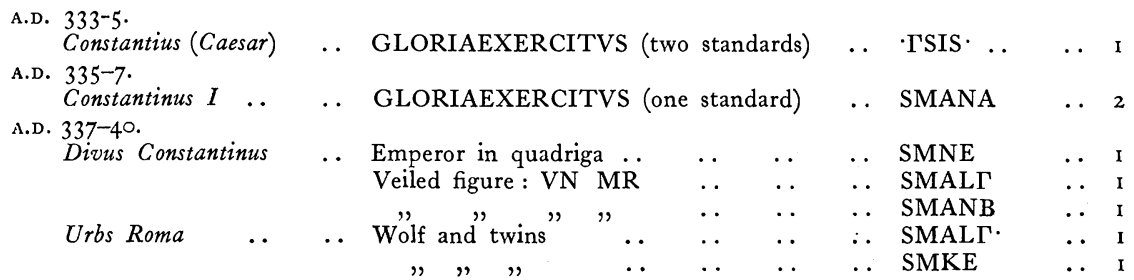


A.D. $340-5$. Constantius Constans

Constantius or Constans .

A.D. $345-7$.

Constantius

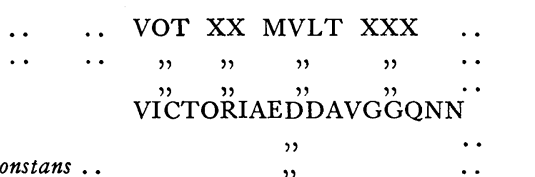

. FELTEMPREPARATIO. Phoenix

$\begin{array}{cccc}\ldots & \text { SMA[ } & \ldots & \text { I } \\ \ldots & \text { SMKE } & \ldots & \text { I } \\ \ldots & \text { ? } & \ldots & \text { I } \\ \ldots & \text { RP (palm) } & \ldots & \text { I } \\ \ldots & ? & \ldots & \text { I } \\ \ldots & \text { ? } & \ldots & 2\end{array}$

. ALEA (star r.). . I

iI. Feltempreparatio. Soldier striking down foe.

(a) Without letter in field.

Alexandria.

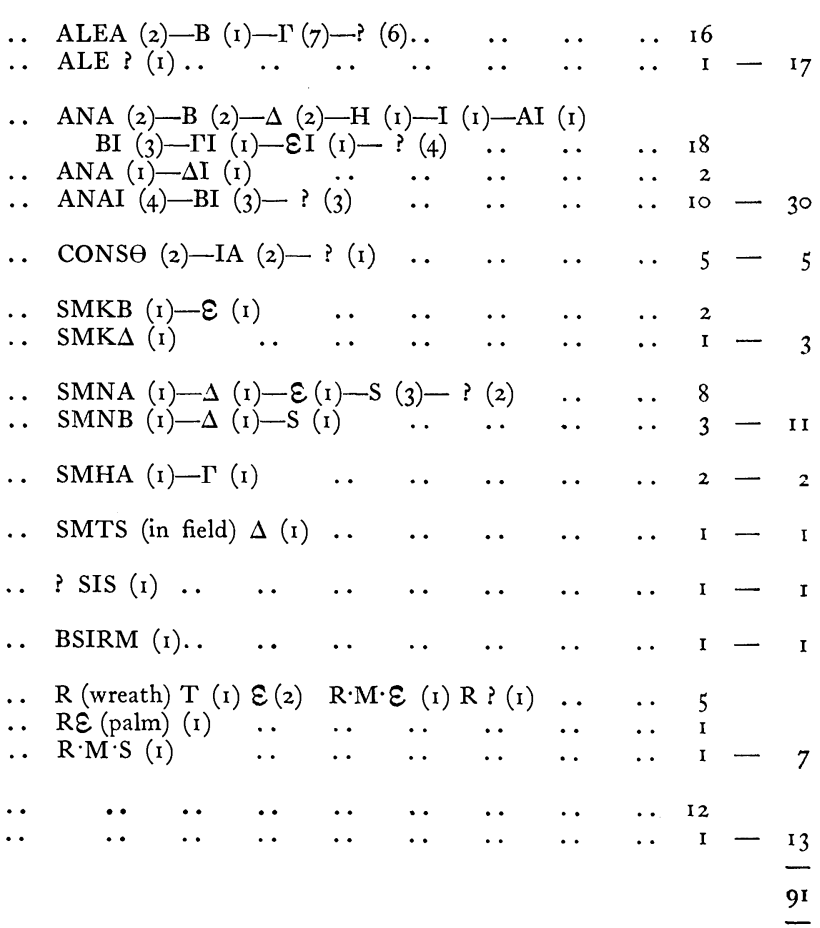

(b) With letter in field.

Alexandria.

Constantius .

Const. Gallus .

Antioch.

Constantius

Const. Gallus .

Julianus Caes.

Constantinople.

Cyzicus.

Constantiu

Nicomedia.

Heraclea.

Constantius

Thessalonica.

Siscia. Sirmium.

Julianus Caes.

Rome.

Constantius

Const. Gallus ..

Mints illegible.

Constantius

Julianus Caes.

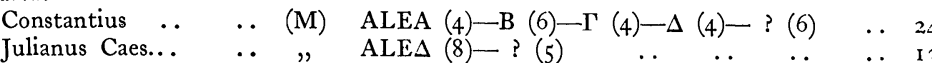
Antioch.

$\begin{array}{lllllll}\text { Julianus Caes... } & \ldots & " & \text { ALE } \Delta(8)-?(5) & \cdots & . & \cdots \\ \text { Constantius } & \ldots & \ldots & (\mathrm{M}) & \text { ANA (I) }-\Gamma(3)-\Delta(\mathrm{I})-\mathrm{S}(3)-\mathrm{H}(2)-\end{array}$

Constantinople. AI (2)-BI (4)-? (3) ..

Constantius $\quad \ldots \quad \ldots \quad(\varepsilon)$ CONSA (I)

$\begin{array}{ll}(\mathrm{E}) & \text { CONSA (I) } \\ (\mathrm{X}) & \text { CONSB (I) - ? (r) } \\ (\mathrm{M}) & \text { CONSA (I) - IA (r) }\end{array}$

(M) $\operatorname{CONSA}(\mathrm{I})$ - IA (I)- ?

Const. Gallus .

(S) CONS? (I) Julianus Caes. Cyzicus.

Constantius $\quad . \quad \quad \ldots \quad(M) \quad \operatorname{SMKA}(3)-B(\mathrm{I})-\Gamma(4)-\varepsilon(\mathrm{I})-\mathrm{S}(3)-?(\mathrm{I}) \quad \mathrm{I}_{3}$

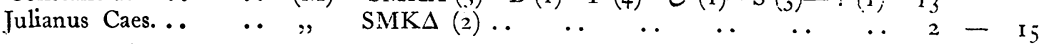




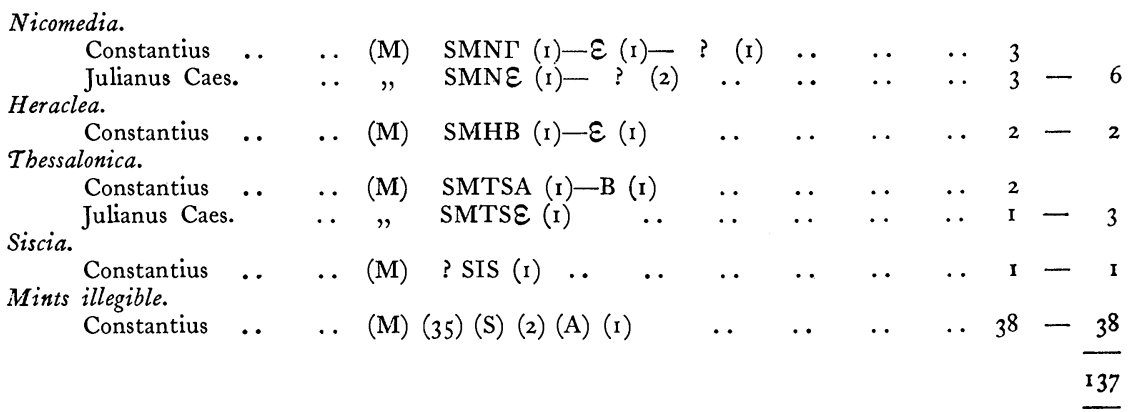

Mints illegible.

(a) or $(b)$

$\begin{array}{llllllllllllllll}\text { Constantius } & \ldots & \ldots & & \ldots & \ldots & \ldots & \ldots & \ldots & \ldots & \ldots & \ldots & 16 & - & & \end{array}$

III. SPESREIPVBLICE.

(a) Without letter in field.

Alexandria.

Constantius $\quad \ldots \quad \ldots \quad$ ALEA (4)-B (10)- $\Gamma(11)-\Delta(7)-\quad ? \quad$ (13) $\quad \ldots \quad 45$

Julianus Caes. .. $\quad . \quad$ ALEB (I) $-\Gamma(2)-\Delta(12)-\quad$ ? $(20) \quad \ldots \quad$.

Antiocb.

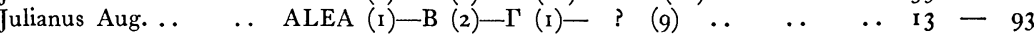

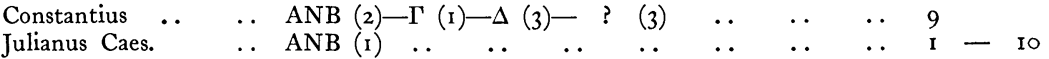

Constantinople.

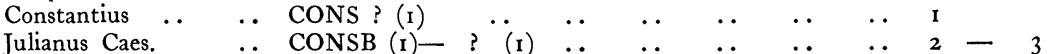

Cyzicus.

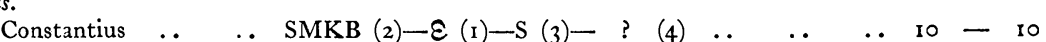

Nicomedia.

Heraclea.

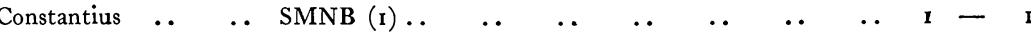

Rome.

$\begin{array}{lllllllllllll}\text { Constantius } & \ldots & \ldots & \text { SMHA }(\mathrm{I})-\mathrm{B}(3) & \ldots & \ldots & \ldots & \ldots & \ldots & 4 & -\end{array}$

Constantius $\quad . \quad \ldots \quad R($ star) $\mathrm{P}(2)-\mathrm{S}(\mathrm{I})-\varepsilon(\mathrm{I})-$ ? (3) R (wreath) $\mathrm{Q}(\mathrm{I})$

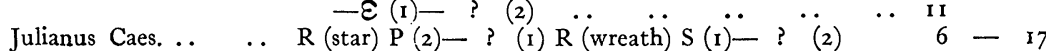

Mints illegible.

Constantius

$4^{\circ}-\frac{40}{178}$

(b) With letter or symbol in field.

Constantinople.

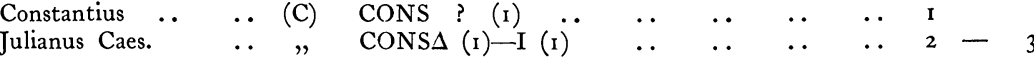
Cyzicus.

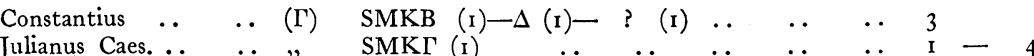

Thessalonica.

\begin{tabular}{llllllllllll} 
Constantius &. & $\ldots$ & (Star) $\operatorname{SMTS\Gamma }(\mathrm{I})$ - & ? & (I) & $\ldots$ & $\ldots$ & $\ldots$ & $\ldots$ & 2 & \\
\hline
\end{tabular}

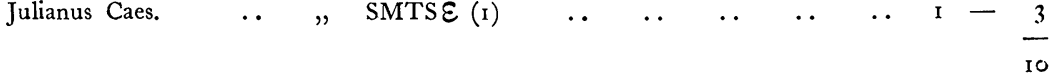

There were also 202 entirely illegible, making a total of 650 coins in the hoard.

The date of the hoard can be fixed as the beginning of the reign of Julianus. Only his earliest issue, of the Spes Reipublicae type, is 
represented in it, and the coins of this type are only of the mint of Alexandria. It was presumably secreted before there had been time for any specimens struck at mints outside Egypt to drift into the country.

The evidence furnished as to the drift of coins into Egypt by this hoard is in general accordance with the conclusions stated in the account of a hoard of Constantinian coins from Egypt in Fourn. Intern. d'Arch. Numism. (1914, pp. I-27). The figures for the different mints may be summarised according to the groups :

I. II. III. III.

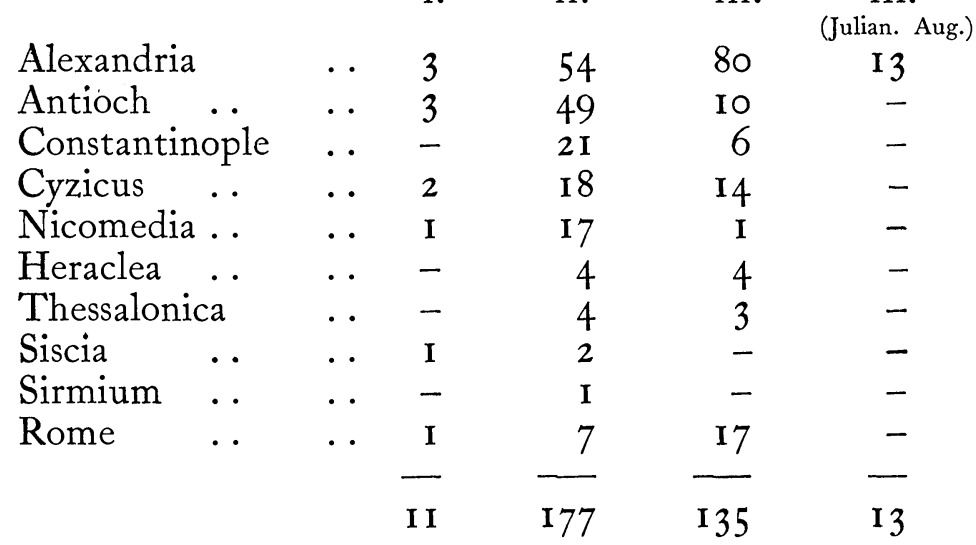

These figures suggest that the drift of coins was a fairly slow process, but that there was a current setting towards Egypt which in the course of five years or so brought appreciable numbers of coins from the main centres of trade to Alexandria and the upper country.

A very noticeable characteristic which appears on a survey of these coins is the extreme carelessness of striking which prevailed at the Alexandrian mint. In the great majority of instances in group III, the centring is bad, and frequently only a small portion of the type is on the flan : several other coins, which may be suspected to be of this mint, show no more than a corner of the legend: the fresh condition of the lettering proves that these had not been long in circulation. Two or three pieces are absolutely blank.

In this connexion it is perhaps not without interest to note that, shortly after the accession of Julianus, the Alexandrian mob slew certain functionaries against whom it bore a grudge, amongst them Dracontius the treasurer ( $\mathrm{Amm}$. Marc. xxii, I I). If Dracontius was responsible for the work of the imperial mint, the anger of the mob had some justification.

\section{HOARD B.}

Note:-The sequence of issues in the period 350-400 does not appear to have been worked out, and further evidence may lead to the modification of the order adopted here, especially as regards 
those types which were peculiar to Western mints, which are scantily represented.

The usual practice of the mints was to strike with the same reverse types for all the Augusti, and consequently the Votis types become somewhat confusing. For instance, the coins of Valentinianus II, Theodosius, and Arcadius with vot x mvlt xx are clearly contemporary; but it is by no means clear to which emperor the decennalia commemorated belong. As the series seems to be parallel in some respects to the issues for Flaccilla, it may perhaps be taken to be for the decennalia of Valentinianus.

There is little variation in the obverse types or legends in the reign of Valentinianus I and his successors. A break in the legend is usual in the Eastern issues, and is almost always at the same point : an exception occurs in the case of Valens, whose Alexandrian issues have DNVALEN SPFAVG, instead of the DNVALENS PFAVG of neighbouring mints.

Other points of variation which cannot conveniently be included in the catalogue follow, arranged according to the numbers assigned to the series in the list:

I. The Lugdunum coin of Constantius II of the Victories type has an uncertain monogram in the field: the Arelate coin has $M$.

V. The Nicomedia coins of Valens have on the reverse in the field r. Q.

VII. One of the Nicomedia coins of Valens has on reverse $B$ in the field 1. : the Constantinople coin has a star in the same position.

$\mathrm{X}$. The Antioch coin of Theodosius has on reverse VOT X MVLT XXX : it is probably meant for this type rather than XII.

XIII. Coins from the mint of Thessalonica seem to read VICTORIA AVG : the others have AVGGG.

On Rome coins there are usually two dots between the Victories on the reverse : in one instance (RS of Theodosius) only one dot is visible.

This seems to be a purely Western type.

XIV. The mint numeral on this type (which is only represented by Thessalonica issues) is usually in the field to 1. : but two specimens of Theodosius do not show any numeral.

XVI. Several of the coins of this issue, from the mint of Alexandria, have a small $\mathrm{T}$ behind the bust on the obverse. They are not distinguishable in style from the others, and are of all three emperors: they have been catalogued separately.

XVIII. On the reverse of this type there is usually $p$ in the field to 1 . But on nearly all the examples from shop $\Delta$ of Alexandria the symbol becomes simply a pellet: on one (of Arcadius) there is nothing in the field.

At Nicomedia there is more variety: the symbols are $\stackrel{\mathfrak{p}}{+},+,($, or $\boldsymbol{\bullet}$, and occasionally nothing.

On coins of Heraclea there is no symbol.

Two specimens of Valentinianus from Antioch show misspellings: one has DNAVLEN - on the obverse, the other ATNA in exergue of the reverse.

XXII. The reverse legend is regularly CONCORDIA AVG at Alexandria, CONCORDIA AVGGG elsewhere. There are two exceptions-an Alexandria coin of Theodosius has AVGGG, and a Constantinople coin of Arcadius AVG.

XXI and XXIII. There is a star behind the head of Honorius on the obverse.

\section{PRE-CONSTANTINIAN.}

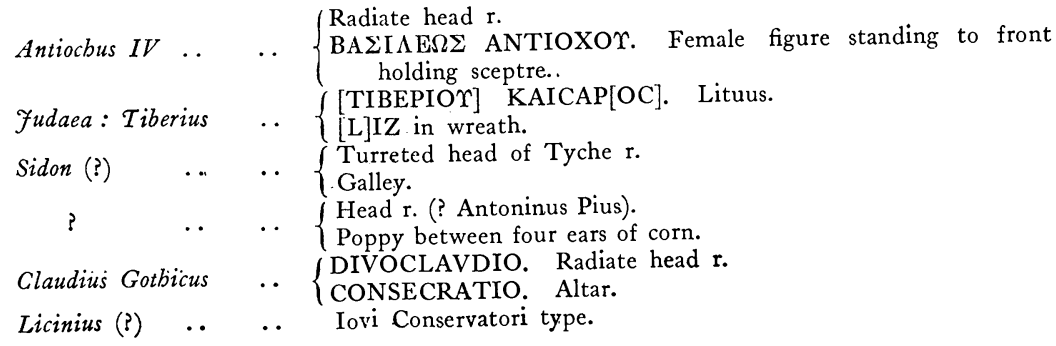




\section{MISCELLANEOUS EARLY ISSUES.}

c. 330 .

Constantinus II (Caesar) .. Legend only $\quad \ldots \quad \ldots \quad \ldots \quad \ldots \quad \ldots \quad$ SMANT (?) $\quad \ldots \quad$. $335-7$.

Helena

$337-40$

Divus Constantinus.. $\quad \ldots \quad$ Emperor in quadriga .. $\quad \ldots \quad \ldots \quad \ldots$ SMALT $\quad \ldots \quad$..

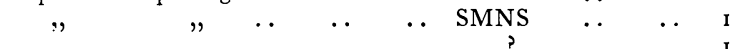

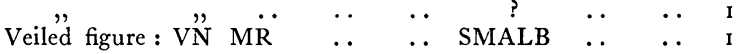

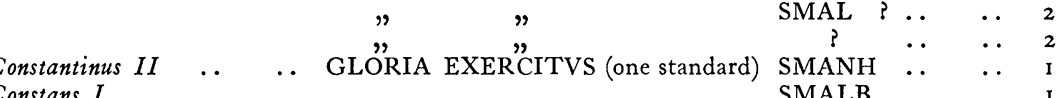

Constantius II

$340-5$

Constans $I \quad \ldots \quad \ldots \quad \ldots$ VOT XV MVLT XX

$\begin{array}{ccccc}? & \ldots & \cdots & \cdots & \\ \text { Constans } I & \ldots & \ldots & \ldots & \text { VOT }\end{array}$

Constantius $I I$

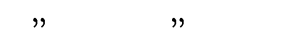

$\begin{array}{ccccc}, & \text { SMALB } & \ldots & \ldots \\ ,, & ? & \ldots & \ldots & 1 \\ , & \text { SMNS } & \ldots & \ldots & \\ ", & \text { CONSS } & \ldots & \ldots & \\ , & \text { SMK } & \ldots & \ldots & \\ , & ? & \ldots & \ldots & \end{array}$

$$
\text { Constantius }
$$

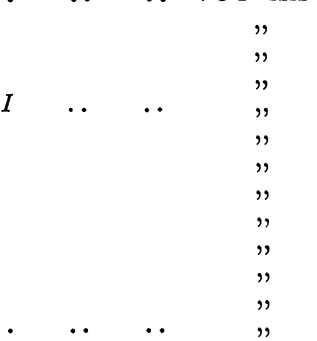

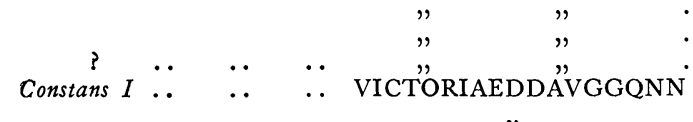

Constantius II

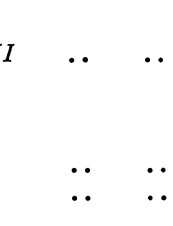

. SMANO $\quad \ldots \quad \ldots \quad$ I

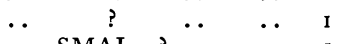

$\begin{array}{lllll}\cdots & \text { SMAL } & \cdots & \cdots & 1 \\ \cdots & & \cdots & 1\end{array}$

. SMKI $\quad$ S $\quad \ldots \quad$ I

.. SMNB $\quad$.. $\quad \ldots \quad$ I

$\begin{array}{lllll} & \text { ? } & \ldots & \ldots & 4\end{array}$

. SMALA .. .. I

. SMALT .. .. I

. SMANS $\ldots \quad \ldots .1$

SMAN $\Delta I \ldots$

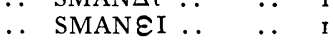

. SMN ? ..

CONSI

$\begin{array}{lllll}\cdots & \text { ? } & \ldots & \cdots & \text { I }\end{array}$

$\begin{array}{lllll}\cdots & \cdots & \cdots & \cdots & 1\end{array}$

$\begin{array}{lllll} & \mathrm{R} \Omega \mathrm{P} & \ldots & \ldots & \mathrm{I}\end{array}$

.. $\mathrm{R}$ ? $\quad \ldots, \quad \ldots \quad 2$

.. ?

$\begin{array}{llll}\text {.. } & \mathrm{R} \odot \mathrm{P} \quad \ldots & \ldots\end{array}$

$\begin{array}{lllll} & \text { R ? } & \ldots & \ldots & 2\end{array}$

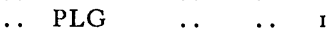

.. ? ARI $\ldots$.

$R$ R

I. Feltempreparatio. Soldier striking down foe. Alexandria.

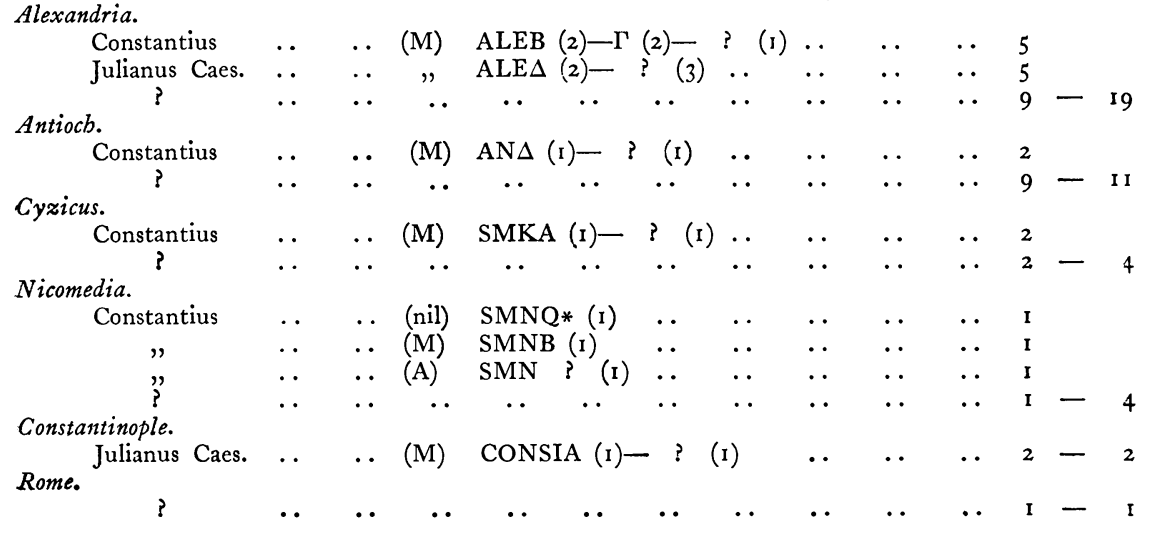


Mints illegible.

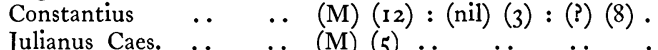

Emperors and mints illegible

$\begin{array}{r}.5-28 \\ \cdots \quad 43-43 \\ \hline 112\end{array}$

III. SPESREIPVBLICE.

Alexandria.

Constantius

Julianus Caes.

Julianus Aug.

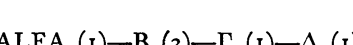

ALA (I)

Antioch.

Constantius

Cyzicus.

Constantius

Julianus Caes.
Julianus Aug.

Nicomedia.

Julianus Aug. .

Constantius ?

Constantinople.

Rome.

Constantius

Mints illegible.

Constantius

Julianus Caes.

Emperors and mints illegible

$$
\begin{aligned}
& \text { ALEA (I)-B (2) - } \Gamma(\mathrm{I})-\Delta(\mathrm{I}) \quad \ldots \quad \text {. }
\end{aligned}
$$

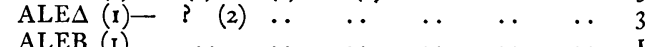

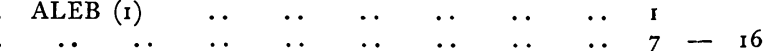

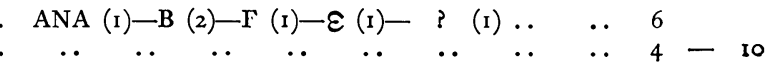

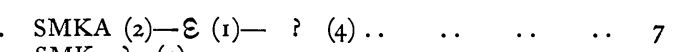

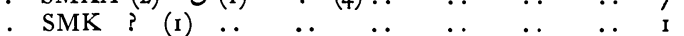

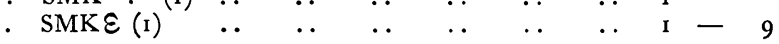

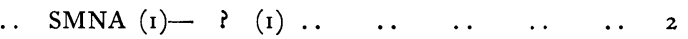

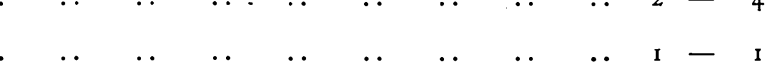

$$
\begin{aligned}
& \mathrm{R} * \mathrm{P}(\mathrm{I})-* \text { ? (2)- } \Omega \text { ? (1)- ? } \\
& \text { (2) } \quad \ldots 6 \\
& \begin{array}{l}
.6 \\
\cdots
\end{array} \quad 4-10 \\
& \begin{array}{lllllllll}
\text {. } & \ldots & \ldots & \ldots & \ldots & \ldots & \ldots & \ldots & 32
\end{array} \\
& \begin{array}{llllllllll}
\text {. } & \ldots & \ldots & \ldots & \ldots & \ldots & \ldots & \ldots & \text { I1 } & -43
\end{array} \\
& \begin{array}{l}
\cdots \\
\cdots \quad 5^{2}-5^{2}
\end{array}
\end{aligned}
$$

Antioch.

IV. RESTITVTORREIP.

Constantinople.

Valentinianus I .. . . ANTA (I)-B (I) Mint illegible.

Valentinianus I ..

. CONSPB (I) ..

Valentinianus I ..

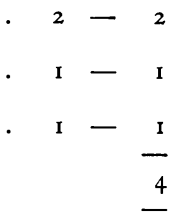

v. GLORIARomanorvm. Emperor dragging captive. Alexandria.

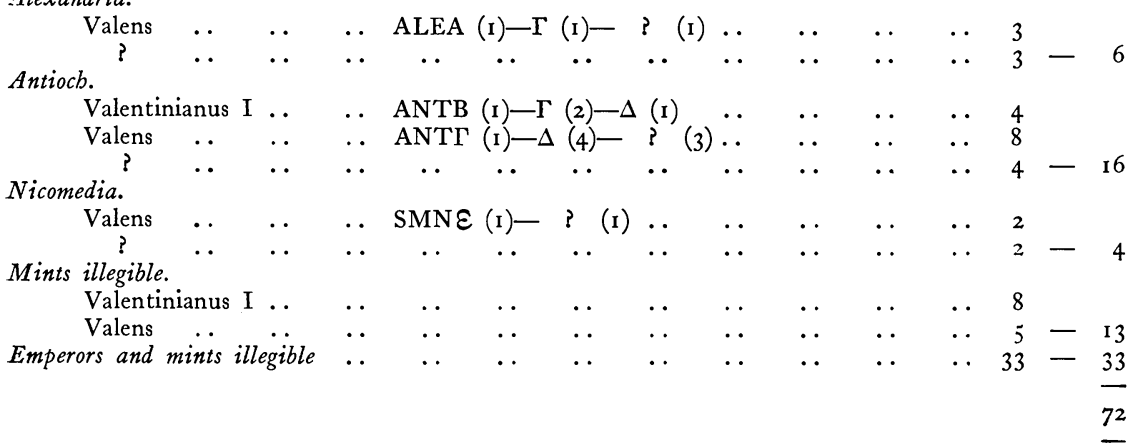


Antioch.

VI. VOT $\mathrm{V}$ MVLT $\mathrm{X}$.

Valentinianus I . ANT ? (I) . Constantinople.

Mint illegible.

Valentinianus I ..

\section{SECVRITASREIPVBLICAE.}

Alexandria.

Valentinianus I ..

Valens

ALEB (I) $-\Gamma(4)-\Delta(3)$

Antiocb.

$$
\underset{?}{\operatorname{Gratianus}} \quad \cdots
$$

ALEA (2)-B (3)-F (5)

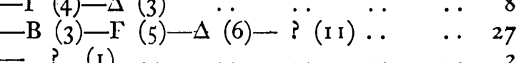
Valen

Cyzicus.

$\begin{array}{lllllllllllllll}\text { alens } & . & \ldots & \ldots & \text { ANT } & \text { ? } & (3) & \ldots & \ldots & \ldots & \ldots & \ldots & \ldots & 3\end{array}$

Nicomedia.

Valens

\begin{tabular}{ccc}
$\begin{array}{c}\text { Valens } \\
?\end{array}$ & $\ldots$ \\
$\begin{array}{c}\text { Constantinople. } \\
\text { Valens }\end{array}$ & $\ldots$ & \\
$?$ & $\ldots$ & $\ldots$ \\
& & \\
\hline
\end{tabular}

Thessalonica.

Rome.

Valentinianus I .. $\quad \ldots \quad$ TESB ( $\mathrm{I}$ )

Trèves.

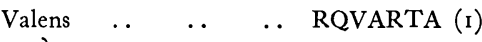

Treves.

Valens $\quad \ldots \quad \ldots \quad \ldots \quad$ TRP (I).

Gratianus $\quad \ldots \quad \ldots \quad$ TRS (I).

Mints illegible.

$\begin{array}{llllllllllll}\text { Valentinianus I } & \ldots & \ldots & \ldots & \ldots & \ldots & \ldots & \ldots & \ldots & \ldots & \ldots & \text { I5 }\end{array}$

$\begin{array}{lllllllllllll}\text { Valens } & \ldots & \ldots & \ldots & \ldots & \ldots & \ldots & \ldots & \ldots & \ldots & \ldots & \ldots & 30\end{array}$

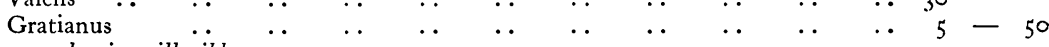

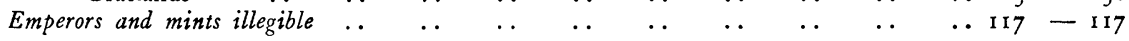

VIII. CONCORDIAAVGGG.

Cyzicus.

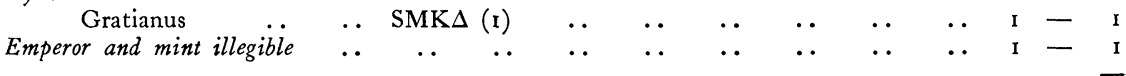

IX. VOT V.

Mint illegible.

Gratianus.

Emperor and mint illegible

X. VOT X MVLT XX.

Antioch.

$\begin{array}{lllllllllllll}\text { Gratianus } & \ldots & \ldots & \operatorname{ANTA}(\mathrm{I})- & ? & (\mathrm{I}) & \ldots & \ldots & \ldots & \ldots & \ldots & 2 \\ \text { Theodosius I } & . & \ldots & \operatorname{ANT} \Delta(\mathrm{I}) & . & \ldots & \ldots & \ldots & \ldots & \ldots & \mathrm{I} & -3\end{array}$ Cyzicus.

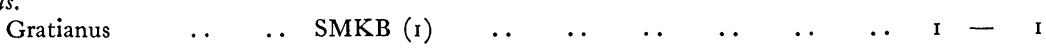


XI. VOT XV MVLT XX.

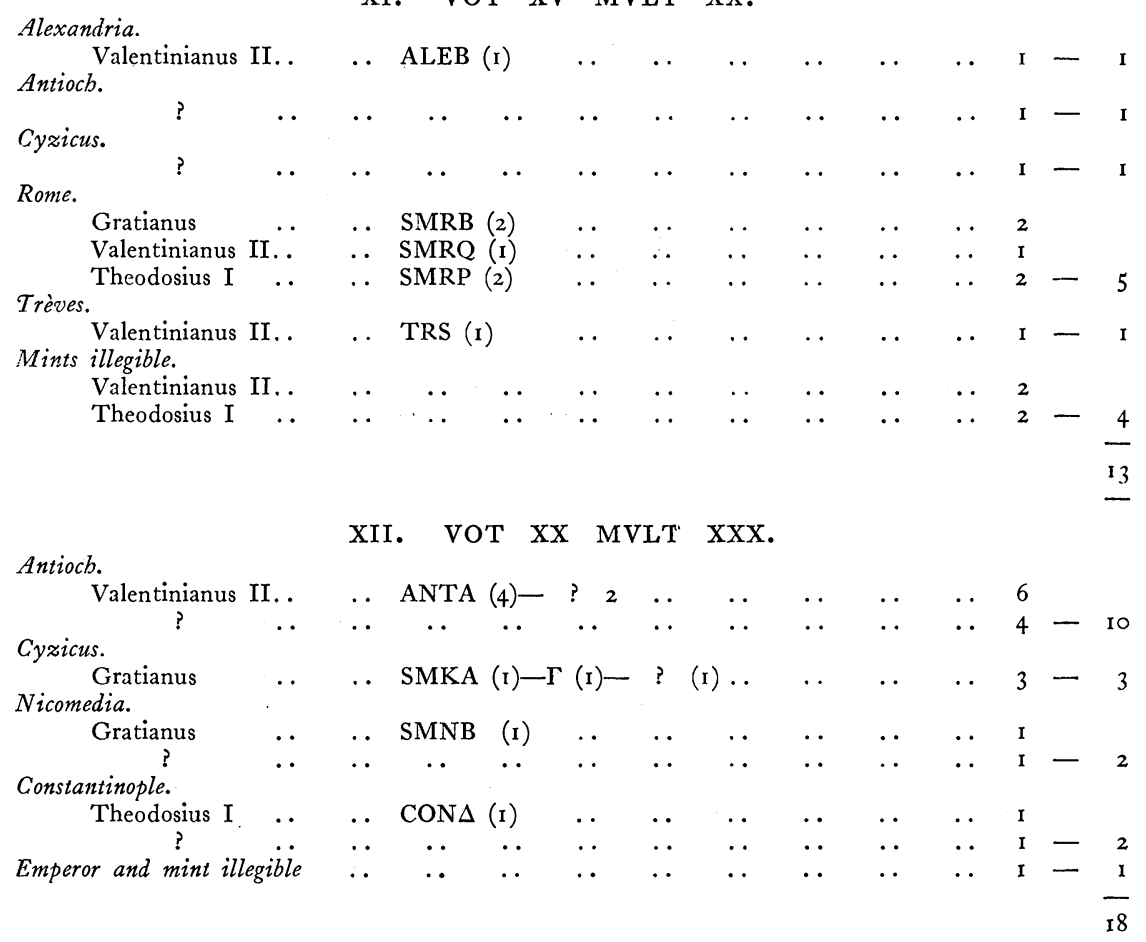

xili. victorianggga. Two Victories facing:

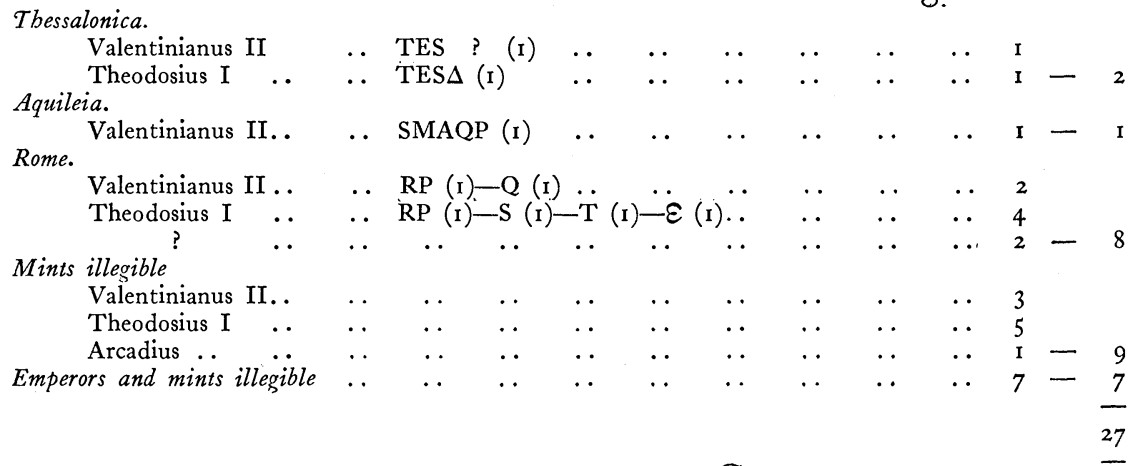

Tbessalonica.

\section{xIV. GLORIAREIPVBLICE. Gateway.}

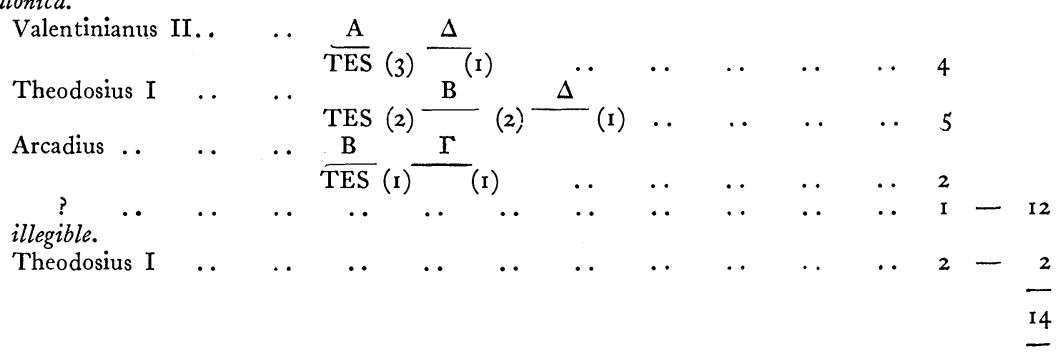


Antioch.

XV. VOT V.

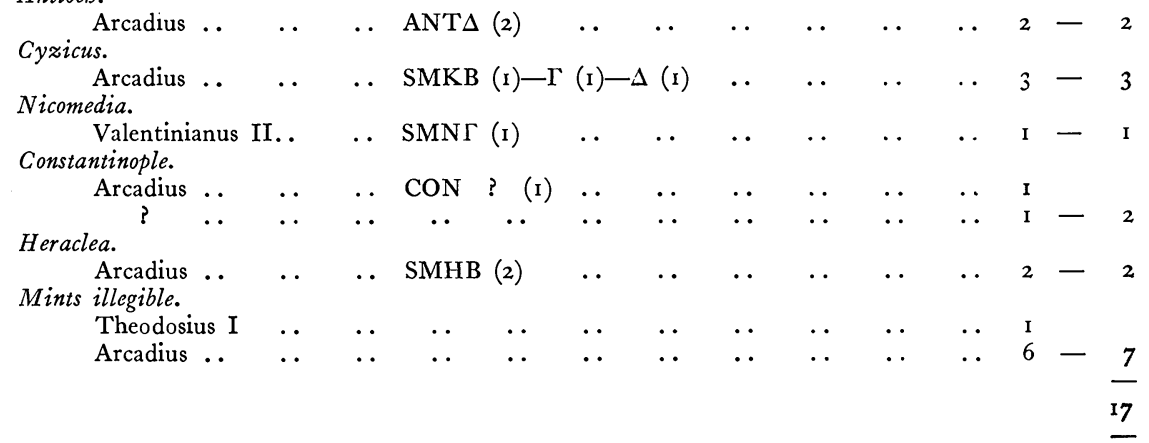

XVI. VOT $\mathrm{X}$ MVLT $\mathrm{XX}$.

Alexandria.

$\begin{array}{lllllllllll}\text { Valentinianus II.. } & \ldots & \text { ALEA (I)-B (I6)- } & ? & (6) . . & \ldots & \ldots & \ldots & 23\end{array}$

Theodosius I $\quad \ldots \quad \ldots$ ALEA (4)-B (2)-T $(26)-\Delta(4)-\quad$ ? (iI) $\quad \ldots \quad 47$

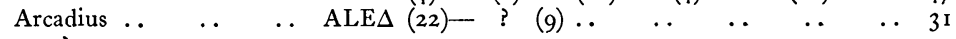

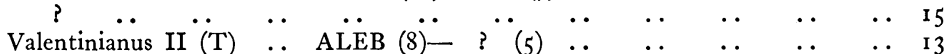

Theodosius I

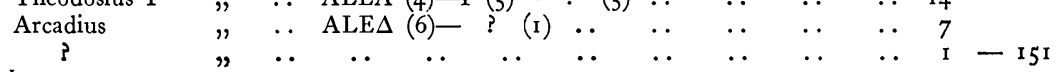

Antioch.

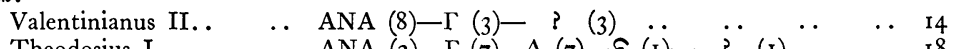

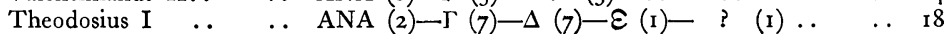

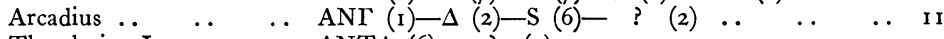

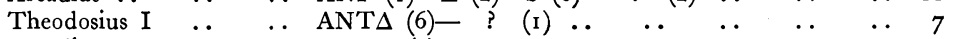

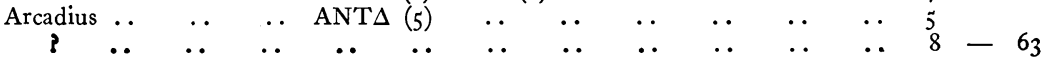

Cyzicus.

Valentinianus II

Nicomedia.

Theodosius I .

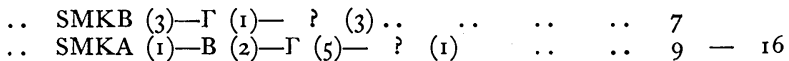

Valentinianus II. .

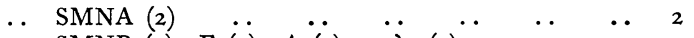

Theodosius I ..

Constantinople.

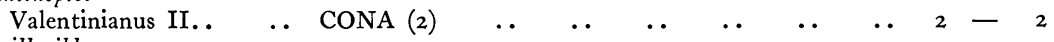
Mints illegible.

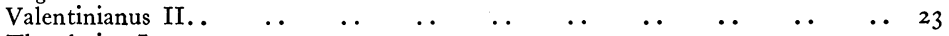

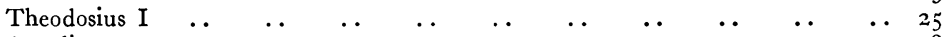

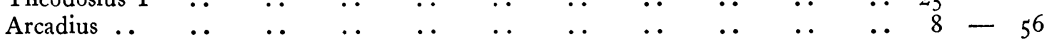

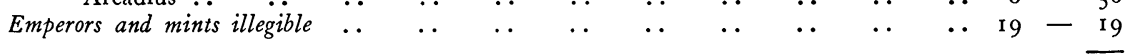

xVia. SAlvsreipvblicae. Victory seated.

Antioch.

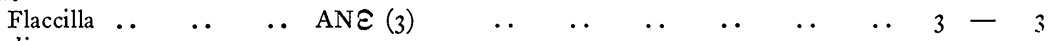

Nicomedia.

Flaccilla $\ldots \quad$.. $\quad$.. $\quad$ SMNA (2)

Constantinople

Flaccilla $\ldots \quad$.. . . CONE (2)

Mints illegible.

$\begin{array}{lllllllllllllllll}\text { Flaccilla } & . & \ldots & \ldots & \ldots & \ldots & \ldots & \ldots & \ldots & \ldots & \ldots & \ldots & \ldots & 3 & -\end{array}$ 


\section{xvir. VictoriaAvgGg. Victory 1.}

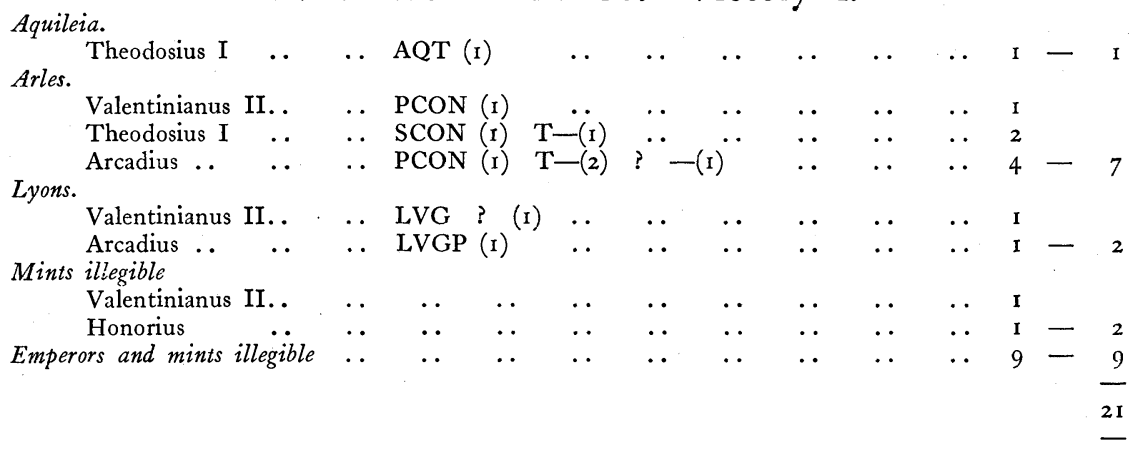

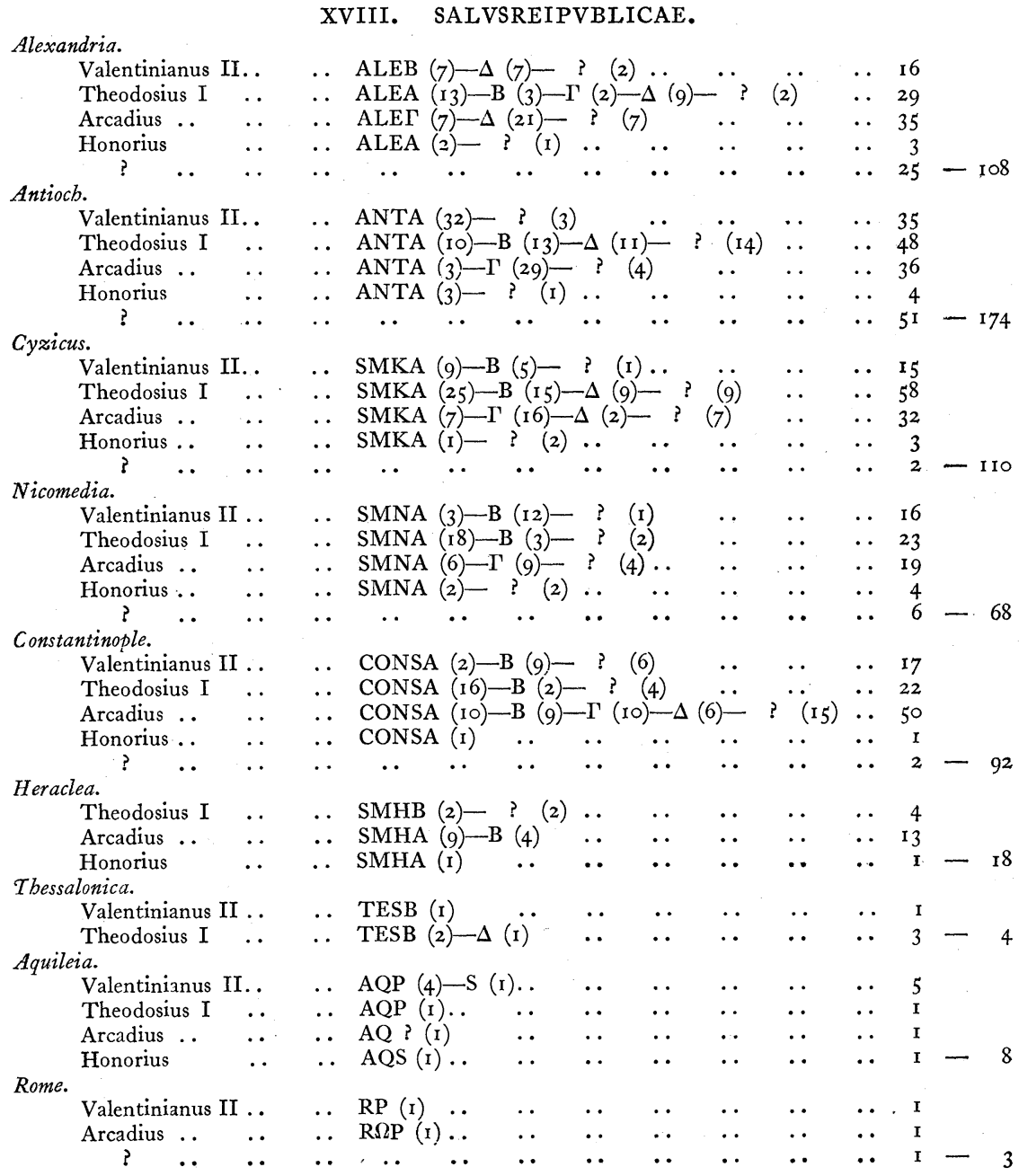


Mints illegible.

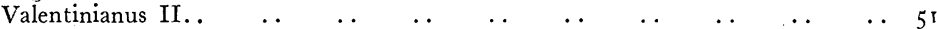

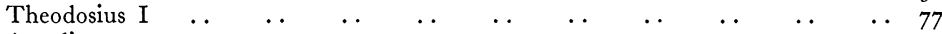

$\begin{array}{llllllllllll}\text { Arcadius .. } & \ldots & \ldots & \ldots & \ldots & \ldots & \ldots & \ldots & \ldots & \ldots & \ldots & 72\end{array}$

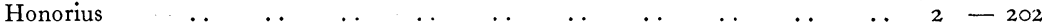

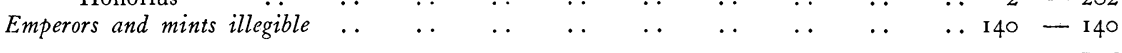

Alexandria.

xix. GLORIAROMANORVM. Emperor riding $r$.

\begin{tabular}{|c|c|c|c|c|c|c|c|c|c|c|c|}
\hline Theodosius I & $\cdots$ & . & ALET (I)- & $?$ (2) & $\ldots$ & $\cdots$ & $\cdots$ & $\cdots$ & $\cdots$ & 3 & \\
\hline $\begin{array}{l}\text { Arcadius . } \\
\text { illegible. }\end{array}$ & . & . & $\operatorname{ALE} \Gamma(\mathrm{I})$ & $\ldots$ & $\cdots$ & $\cdots$ & . & $\cdots$ & . & I & - \\
\hline Theodosius I & $\ldots$ & . & .. & . & $\ldots$ & $\ldots$ & . & . & . & I & - \\
\hline
\end{tabular}

xx. VRbsromafelix. Emperor holding Victory.

Rome.

Honorius .. $\quad . \quad \cdots \frac{\mathrm{OF} P}{\operatorname{SMROM}}(6) \stackrel{\mathrm{S}}{(2)} \stackrel{\mathrm{T}}{(2)} \stackrel{\varepsilon}{{ }_{(3)}} \quad \cdots \quad \ldots \quad \mathrm{r} 3-\mathrm{r} 3$

Mint illegible.

Theodosius I

XXI. GLORIAROMANORVM. Three emperors.

Mint illegible.

Honorius..

xxil. concordianvg(GG). Cross.

Alexandria.

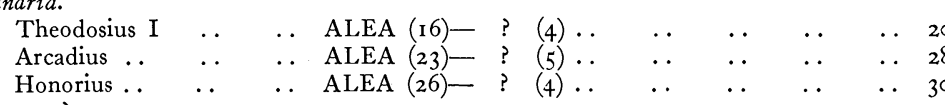

Antioch.

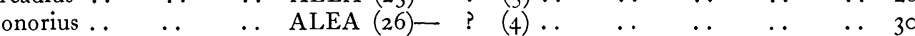

Theodosius I

Arcadius

Honorius .

. $\quad$. ANTA (2)- $\mathrm{A}(2)-\quad ? \quad(\mathrm{I})$

Cyzicus.

Arcadius .

Nicomedia.

$$
\text { ? }
$$

Theodosius I

Arcadius .

Honorius .. ?

Constantinople.

Theodosius I

Arcadius .

Honorius .

.. $\quad$. ANTA (3)-T (I) - ? (2).

.. $\quad . \quad$ ANTA $(5)-\Gamma(\mathrm{I})$

(2)

$\therefore$ 17 - 95

Heraclea.

Arcadius .. $\quad \ldots \quad \ldots \quad$ SMHA (2)

Mints illegible.

$\begin{array}{llllllllllll}\text { Theodosius I } & \ldots & \ldots & \ldots & \ldots & \ldots & \ldots & \ldots & \ldots & \ldots & \ldots & 6\end{array}$

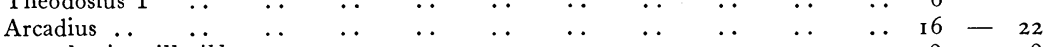

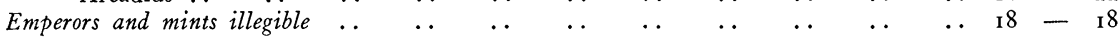


xxiII. Gloriaromanorvm. Two emperors.

Heraclea.

Honorius

.. . $\quad$ SMHA (r)

Mint illegible.

Honorius

$$
\begin{aligned}
& \text {. } . . \quad \text {. } \quad \text { I }- \text { I } \\
& \begin{array}{lllll}
\cdot & \cdots & \text { I } & -\frac{\mathrm{I}}{2}
\end{array}
\end{aligned}
$$
Mint illegible.

xxiv. virtvsexerciti. Emperor crowned by Victory.

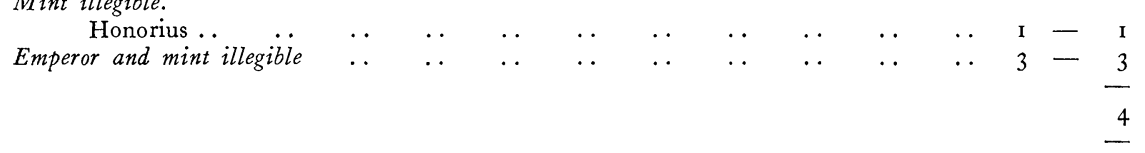
Rome.

xxv. GLORIaromanorvm. Emperor dragging captive.

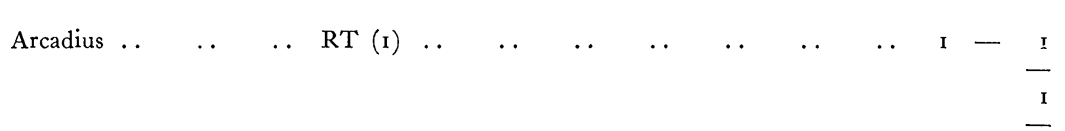

OBVERSE BROCKAGES.

Arcadius
Honorius

BARBAROUS IMITATIONS.

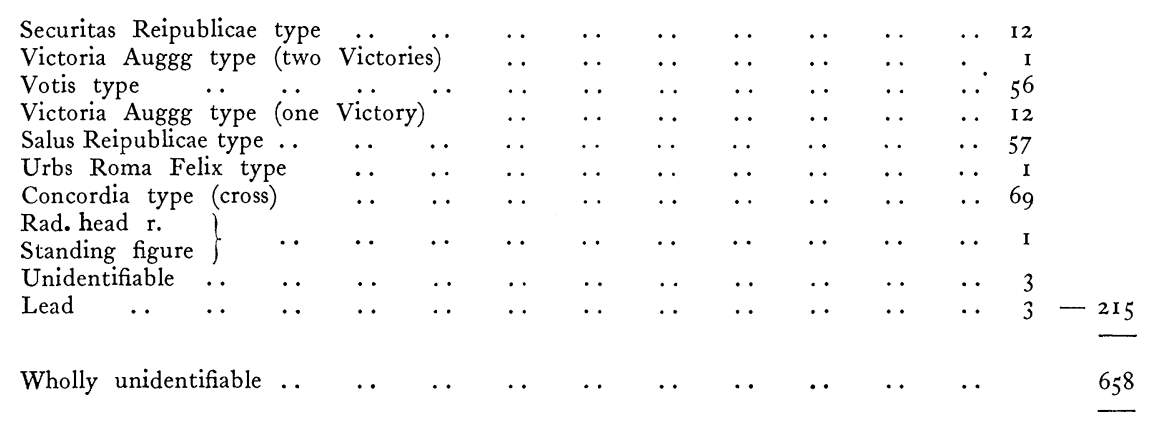

This hoard was found at Hawara in the Fayûm.

As regards the date of deposit, many of the coins of Theodosius, Arcadius, and Honorius, especially of series xxII, were in very fresh condition. There were no types included which can be dated after the death of Arcadius, unless it is supposed that the barbarous imitations, most of which were little worn, were struck later. But these were all (so far as the origin of the types can be determined) copied from the coins of Honorius and earlier emperors, and there is no strong ground for considering them as other than virtually contemporary with the imperial issues with which they circulated and which they imitated. The hoard may therefore be taken to have been formed about A.D. 400-4IO.

The following table gives the numbers of specimens of each series from the various mints of the empire. Series $\mathrm{Ix}$, xxI, and xxIv are omitted, as no example in these three has the mint-name preserved. 


\begin{tabular}{|c|c|c|c|c|c|c|c|c|c|c|c|c|c|c|}
\hline 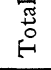 & $\stackrel{\tilde{o}}{+}$ & & ڤิ & $\stackrel{\infty}{\stackrel{0}{0}}$ & $\stackrel{\text { త্ }}{ }$ & $\tilde{s}$ & $\stackrel{్}{\Omega}$ & 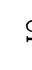 & & 으 & $\infty$ & $m$ & $m$ & $\stackrel{\infty}{m}$ \\
\hline$\underset{x}{x_{x}}$ & 1 & 1 & 1 & 1 & 1 & 1 & 1 & 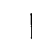 & & $M$ & 1 & 1 & 1 & $r$ \\
\hline$\underset{x}{\stackrel{y}{x}}$ & 1 & 1 & 1 & 1 & 1 & $m$ & 1 & 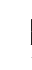 & & 1 & 1 & 1 & 1 & H \\
\hline$\vec{\forall}$ & 으 & น & $N$ & $N$ & $a$ & N & 1 & 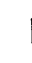 & & 1 & 1 & 1 & I & 占 \\
\hline$\ddot{x}$ & I & 1 & 1 & 1 & 1 & 1 & 1 & 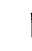 & & $m$ & 1 & 1 & 1 & $m$ \\
\hline$\ddot{x}$ & + & 1 & 1 & 1 & 1 & I & I & 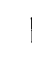 & & 1 & 1 & $!$ & 1 & + \\
\hline$\underset{\forall}{\Delta}$ & $\stackrel{\infty}{0}$ & $\underset{\sim}{ \pm}$ & $\stackrel{\circ}{\circ}$ & 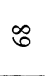 & สু & $\stackrel{\infty}{\infty}$ & + & $\alpha$ & & m & 1 & 1 & I & $\stackrel{\text { no }}{\infty}$ \\
\hline $\overrightarrow{n_{x}}$ & 1 & 1 & 1 & 1 & 1 & 1 & 1 & 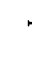 & & 1 & $n$ & $N$ & 1 & 움 \\
\hline$\stackrel{5}{x}$ & 도 & $\because$ & $\stackrel{\circ}{\circ}$ & $\stackrel{\circ}{\circ}$ & + & 1 & 1 & & & 1 & 1 & 1 & 1 & 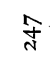 \\
\hline$\vec{x}$ & 1 & $N$ & m & $H$ & $\mathrm{~N}$ & N & 1 & & & 1 & 1 & I & 1 & $\circ$ \\
\hline 吾 & 1 & $i$ & 1 & 1 & 1 & 1 & $\cong$ & & & I & 1 & 1 & 1 & $\Xi$ \\
\hline 获 & 1 & 1 & 1 & 1 & 1 & 1 & N & , & & $\infty$ & 1 & 1 & 1 & $\Rightarrow$ \\
\hline$\exists$ & 1 & $\stackrel{\circ}{\circ}$ & $m$ & $\mathrm{~N}$ & $N$ & 1 & 1 & & & 1 & 1 & 1 & 1 & $\hat{A}$ \\
\hline $\bar{x}$ & $m$ & $m$ & $H$ & 1 & 1 & 1 & 1 & & & in & 1 & 1 & $r$ & $\sigma$ \\
\hline * & 1 & $m$ & $m$ & 1 & 1 & I & 1 & & & I & 1 & 1 & 1 & + \\
\hline$\Xi$ & 1 & 1 & $m$ & 1 & 1 & 1 & 1 & & & 1 & 1 & 1 & 1 & $M$ \\
\hline 5 & $\Re$ & $\stackrel{\infty}{\sim}$ & N & + & $\mathrm{N}$ & 1 & 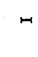 & & & + & 1 & 1 & $N$ & $\stackrel{\circ}{\circ}$ \\
\hline 5 & 1 & $r$ & 1 & 1 & - & 1 & 1 & & & 1 & 1 & 1 & 1 & $N$ \\
\hline$>$ & 6 & $\stackrel{\sim}{\circ}$ & 1 & + & I & 1 & 1 & & & 1 & 1 & 1 & 1 & $b_{i}$ \\
\hline$z$ & 1 & N & 1 & 1 & $m$ & I & 1 & & & I & 1 & 1 & 1 & $m$ \\
\hline 思 & $\stackrel{\circ}{\circ}$ & $\stackrel{\circ}{\circ}$ & $\sigma$ & + & - & I & 1 & & & $\stackrel{\circ}{\circ}$ & 1 & 1 & 1 & in \\
\hline$\exists$ & I & $\exists$ & + & + & $\mathrm{N}$ & 1 & I & & & - & 1 & 1 & 1 & 7 \\
\hline- & $\infty$ & 6 & N & + & t & I & 1 & & & \pm & 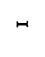 & $m$ & 1 & $q$ \\
\hline$\underset{\Sigma}{\dot{s}}$ & 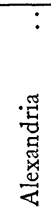 & 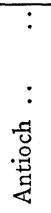 & $\begin{array}{c}: \\
\text { : } \\
\text { 芯 } \\
\text { J }\end{array}$ & 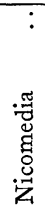 & 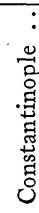 & 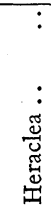 & 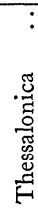 & 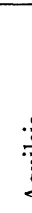 & : & 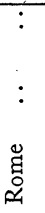 & $\begin{array}{l}: \\
\stackrel{\ddot{m}}{\sharp}\end{array}$ & $\begin{array}{l}: \\
\\
\text { : } \\
\text { 今 }\end{array}$ & 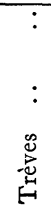 & $\underset{H}{\overrightarrow{0}}$ \\
\hline
\end{tabular}


The presence of so many barbarous imitations of the imperial coinage in this hoard lends it a special interest. Egypt was always a happy hunting-ground of the forger of coins (see F.E.A. iv, I85) : in Ptolemaic times plated silver tetradrachms and leaden imitations of bronze were produced, and in the early part of the fourth century enormous quantities of cast bronze coins were in circulation. But the imitations of this period differ from the earlier ones in being struck, apparently from unfixed dies, as two specimens in the hoard from the same dies have them placed in reversed positions, and not a few show obverse and reverse at an angle. In the discussion of hoard $\mathrm{A}$ it was pointed out that the work of the Alexandrian mint under Julianus was exceptionally careless; and it might be supposed that the mint had gone from bad to worse in the following fifty years, and that these barbarous issues actually represent the work of the government officials. But there are many examples of the Alexandrian issues in this hoard, and these show that there was in fact some improvement in the productions of the mint under Valens and Theodosius : at any rate it was able to turn out coins with an intelligible legend. The specimens classed as barbarous sometimes show a fair attempt at rendering the types, but the legends are always hopelessly confused, varying from a meaningless jumble of letters to a mere ring of dots. Some also are copied from types which were not struck at Alexandria officially, e.g. the Urbs Roma Felix type of Honorius. It would seem probable that some enterprising but unskilful persons in Upper Egypt engraved dies and struck coins on their own account, imitating as best they could the official coins in circulation.

The degradation of types is interesting, as the whole process of breaking up a figure, e.g. Victory, into a few disconnected lines can be traced.

At first sight it appears strange that such extremely poor copies of coins should have been accepted as current. But the composition of the hoard shows that anything almost would pass muster, as indeed is the case to this day in some parts of the Near East. A bronze coin of Antiochus IV could have no sort of legal backing in the fourth century A.D., and would be technically on the same footing as the most recent imitation. And the presence in the hoard of three bits of lead bearing a superficial resemblance to coins suggests that not even good metal was guaranteed, apart from its possible tokenvalue. Moreover, many of the coins of the imperial series were worn almost smooth, so that the types could barely be distinguished, and chipped away at the edges : and there was a large number of pieces of bronze of which the most that can be said is that they have the appearance of having once been Roman imperial coins of the fourth century.

As a matter of fact, the coins were merely current as tokens, with 
very little relation to their metal value. The depreciation of the currency in Egypt in the fourth century went forward at a pace which would have been thought extraordinary five years ago. The billon tetradrachm of the Alexandrian mint, which was reckoned as the equivalent of the denarius, rapidly disappeared from circulation after the reform of 296, and the statements of reckoning in papyri, which had previously been based on the drachma, began to be given in denarii. The fall in the value of the denarius made it an impossibly small unit : as early as 316 the 'myriad' appears, and by 340 it had become normal. The prices quoted in the fourth century show that no lower unit than this would have been of any practical use-e.g. at Oxyrhynchos in 362 the value of a hide was $75^{\circ}$ myriads of denarii (P. Oxy. I057).

The only coinage current in Egypt was composed of the gold solidus and this bronze: and the equations cited in the papyri give some clue to the valuation of the bronze. In a late fourth-century letter (P. Oxy. I223), the writer states that the solidus has dropped to 2020 myriads: and other papyri of the same period make this equation seem probable. It would therefore appear likely that these little bronze coins of the time of Theodosius passed current as myriads of denarii : there is nothing impossible in this from the point of view of metal values, as the average weight of the coins is about one gramme, so that the equivalent of a solidus would be about 20 kilos of bronze coinage, and it is not probable that this weight of bronze would be worth anything approaching a solidus as metal.

The chaos of the Egyptian currency was indeed so great that in the fifth century recourse had to be made to barter and payments in kind, and the myriad disappears from documents of account, to be replaced as the century drew to a close by the gold nomisma as the standard of reckoning, with fractional statements in carats.

A representative series of coins from these two hoards has been presented to the British Museum by Professor Petrie. 